\title{
Vaccines Against Viral Infections
}

\begin{abstract}
Vaccines are one of the miracles of modern medicine. Without vaccines, the population-particularly children-would be troubled with multitudinous infectious diseases such as diphtheria, scarlet fever, whooping cough, and measles, just to name a few. Vaccines are available against both viral and bacterial infections; they have saved millions of lives and continue to do so. The World Health Organization hopes to have vaccinated all children under a year old against most infectious diseases by 2020. The history of the public's acceptance of vaccines has been a stormy one. Anti-vaccination movements have been active since the creation or development of the smallpox vaccine in the eighteenth century and in government-mandated vaccination until the present. An example of this is the fabricated information spread about the relationship between measles vaccine and autism. A successful polio vaccine was developed in the 1950s thanks to the research of three groups, led by Koprowski, Salk and Sabin, although each of these vaccines has its advantages and disadvantages. An oral vaccine has the advantage of ease of administration and a herd effect. Polio vaccine workers have become targets of extremists in Nigeria and Pakistan. Recently, recombinant DNA technology, was used to develop new vaccines in order to avoid the side effects, since live virus is not involved. The future may see the production of vaccines in edible plants, allowing for cheap production and ease in worldwide distribution.
\end{abstract}

\subsection{Introduction}

In 2011, it is estimated that 6.9 million children under five died, mostly from diseases that are preventable by vaccination. This number is down from 12.4 million who died in 1990; thus, in 11 years, over 5 million lives were saved as a 
result of the development of new vaccines, and a World Health Organization campaign to vaccinate children in Africa, India and other less-developed countries, through the "Global Vaccine Action Plan" (GVAP). The most common causes of death among young children are acute respiratory infections, diarrhea from contaminated sources, measles, malaria, HIV and malnutrition, and most of these deaths could have been prevented by vaccination. Table 19.1 lists the vaccines that are administered to children (and adults) worldwide, when they were developed or licensed, and the number of cases and coverage where available.

The World Health Organization launched a program, "Decades of VaccinesGlobal Action Plan 2011-2020" to promote more equitable access to vaccines throughout the world. One of the aims of this program is the complete eradication of poliovirus. However, this program has already run into trouble, since inhabitants of the tribal areas of Pakistan, and certain groups in Nigeria, see the vaccination as a CIA plot, and this has hindered the complete elimination of polio. Polio workers carrying out the vaccination program, were shot and killed in Pakistan by Al Qaeda and the Taliban. This results from the participation of a physician involved in the polio vaccine campaign helping the US military in physicians to collect information from the Osama bin Laden household which aided in identifying the Al Qaeda leader.

When the WHO launched the expanded program on immunization in 1974, less than $5 \%$ of the world's children under age one were immunized against killers such as polio, measles, and whooping cough; by 2020, the aim is to reach $80-90 \%$ of these children with available vaccines. It is currently estimated that $83 \%$ of the world's children under age one receive vaccines against most killer diseases, and new vaccines against hepatitis A and B are now administered (see Table 19.1). However, one-fifth of the world's children-about 22.4 million infants-are not immunized against these diseases. An estimated 1.5 million children died from vaccine-preventable diseases in 2011.

It is obvious that vaccination has had a profound effect on the incidence of disease in the U.S., and attempts to vaccinate the rest of the world against many of these diseases are under way. Smallpox has been eradicated and polio is near eradication. Tables 19.2 and 19.3 illustrate the effect those vaccines have had on health in the U.S.

There has been much discussion recently on whether there is the need to vaccinate children against so many infectious diseases. In particular, the necessity of vaccinating against measles has been questioned, with the troubling menace of measles outbreaks occurring in various parts of the world, specifically in the U.K. Our guard against a number of known childhood diseases has been lowered because of misinformation on the Internet, or even in scientific publications relating vaccines to autism and other pathologies. Neglecting polio vaccination has resulted in epidemics in various parts of the Middle East and Pakistan, and in India in 2013. Just this year, emergency vaccinations against polio had to be given in Israel and Syria.

The history of vaccine development, but more so the history of the public's acceptance of vaccines, has been a stormy one. Anti-vaccination movements have been active since the introduction of the smallpox vaccine and 
Table 19.1 Available vaccines and date of introduction

\begin{tabular}{|c|c|c|c|c|}
\hline Disease & $\begin{array}{l}\text { Year of vaccine } \\
\text { development or license }\end{array}$ & $\begin{array}{l}\text { Number of } \\
\text { cases }(2012)\end{array}$ & $\begin{array}{l}\text { Percentage } \\
\text { vaccine } \\
\text { coverage } \\
(\%)\end{array}$ & Comments \\
\hline Diphtheria & $1920 \mathrm{~s}$ & 4,425 & 83 & $\begin{array}{l}\text { Caused by } \\
\text { corynebacterium } \\
\text { diphtheria }\end{array}$ \\
\hline Measles & $\begin{array}{l}1963 \text { Edmonston B } \\
\text { strain, attenuated }\end{array}$ & 227,245 & 84 & $\begin{array}{l}\text { Caused by } \\
\text { paramyxovirus; highly } \\
\text { lethal } \\
(50 \%)\end{array}$ \\
\hline Mumps & $\begin{array}{l}\text { First strain developed in } \\
\text { 1949. Today at least } 10 \\
\text { strains of vaccine }\end{array}$ & $\begin{array}{l}\text { Endemic; } \\
\text { numbers not } \\
\text { available }\end{array}$ & 59 & $\begin{array}{l}\text { Predominantly childhood } \\
\text { disease }\end{array}$ \\
\hline Polio & 1950-1956 & 220 & 99 & $\begin{array}{l}\text { Attenuated vaccines } \\
\text { developed by Sabin and } \\
\text { Koprowski, "killed" } \\
\text { vaccine by Salk }\end{array}$ \\
\hline Yellow fever & $\begin{array}{l}\text { 1936, developed by } \\
\text { Theiler }\end{array}$ & $\begin{array}{l}200,000 \text { or } \\
\text { more }\end{array}$ & 37 & $\begin{array}{l}\text { Increase in incidence } \\
\text { despite vaccine }\end{array}$ \\
\hline Smallpox & 1796 (vaccinia) & 0 & $\begin{array}{l}\text { No longer } \\
\text { applied }\end{array}$ & $\begin{array}{l}\text { Eradicated in } \\
1977\end{array}$ \\
\hline Hepatitis A & 1993-1996 & $\begin{array}{l}1.4 \text { million/ } \\
\text { year }\end{array}$ & $\begin{array}{l}\text { Worldwide } \\
\text { endemic }\end{array}$ & \\
\hline Hepatitis B & 1981 & $\begin{array}{l}240 \text { million } \\
\text { chronic } \\
\text { infections }\end{array}$ & $\begin{array}{l}\text { Not } \\
\text { covered }\end{array}$ & $\begin{array}{l}\text { 1st recombinant vaccine. } \\
600,000 \text { deaths per year }\end{array}$ \\
\hline Papilloma & 2006-2007 & $\begin{array}{l}529,000 \text { new } \\
\text { cases of } \\
\text { cervical } \\
\text { cancer in } \\
2012\end{array}$ & $\begin{array}{l}\text { Not } \\
\text { covered }\end{array}$ & $\begin{array}{l}274,000 \text { deaths due to } \\
\text { cervical cancer }\end{array}$ \\
\hline Rabies & $\begin{array}{l}1885 \text { (Pasteur attenuated } \\
\text { vaccine), } 1967 \text { killed } \\
\text { vaccine: } 1984 \\
\text { recombinant vaccine: }\end{array}$ & $\begin{array}{l}55,000 \text { die per } \\
\text { year, mostly } \\
\text { in Africa and } \\
\text { Asia }\end{array}$ & $\begin{array}{l}15 \text { million } \\
\text { receive } \\
\text { vaccine per } \\
\text { year }\end{array}$ & \\
\hline $\begin{array}{l}\text { Varicella } \\
\text { (Chickenpox) }\end{array}$ & $\begin{array}{l}1988 \text { in Japan and Korea, } \\
1995 \text { in USA }\end{array}$ & 6,800 deaths & Not known & Mild disease \\
\hline $\begin{array}{l}\text { Zoster } \\
\text { (Shingles) }\end{array}$ & 2006 & N/A & N/A & $\begin{array}{l}\text { For people over } 60 \text { years } \\
\text { of age }\end{array}$ \\
\hline
\end{tabular}


Table 19.1 (continued)

\begin{tabular}{lllll}
\hline Disease & $\begin{array}{l}\text { Year of vaccine } \\
\text { development or license }\end{array}$ & $\begin{array}{l}\text { Number of } \\
\text { cases }(2012)\end{array}$ & $\begin{array}{l}\text { Percentage } \\
\text { vaccine } \\
\text { coverage } \\
(\%)\end{array}$ & Comments \\
\hline Influenza & $\begin{array}{l}\text { 1945, first given to army } \\
\text { personnel in USA }\end{array}$ & N/A & N/A & $\begin{array}{l}\text { Vaccine changes } \\
\text { annually. Tripartite, } \\
\text { containing three different } \\
\text { viruses }\end{array}$ \\
\hline Rubella & 1969 & 100,000 & $\begin{array}{l}\text { Most } \\
\text { countries } \\
\text { do not } \\
\text { vaccinate }\end{array}$ & $\begin{array}{l}\text { Given as part of MMR } \\
\text { vaccine }\end{array}$ \\
\hline Rotavirus & 2006 & & $\begin{array}{l}\text { No } \\
\text { coverage }\end{array}$ & $\begin{array}{l}\text { Causes severe diarrhea } \\
\text { in children }\end{array}$ \\
\hline
\end{tabular}

Table 19.2 The impact of vaccination on the total incidence of viral disease comparing the average incidence in 1930-1950 with the year 2010 (USA)

\begin{tabular}{llll}
\hline Disease & $\begin{array}{l}\text { Annual morbidity in twentieth } \\
\text { century }\end{array}$ & $\begin{array}{l}\text { Reported cases in } \\
2010\end{array}$ & $\begin{array}{l}\text { Decrease } \\
(\%)\end{array}$ \\
\hline Smallpox & 29,005 & 0 & 100 \\
\hline Polio (paralytic) & 16,316 & 0 & 100 \\
\hline Measles & 530,217 & 61 & $>99$ \\
\hline Mumps & 162,344 & 2,528 & 98 \\
\hline Rubella & 47,745 & 6 & $>99$ \\
$\begin{array}{l}\text { Congenital rubella } \\
\text { syndrome }\end{array}$ & 152 & 0 & 100
\end{tabular}

Data from table derived from http://www.cdc.gov/vaccines/pubs/pinkbook/downloads/ appendices/G/impact-of-vaccines.pdf

Table 19.3 Comparison of pre-vaccine era with current morbidity estimates

\begin{tabular}{llll}
\hline Disease & Pre-vaccine era annual & 2008 estimates & Decrease (\%) \\
\hline Hepatitis A & 117,333 & 11,049 & 91 \\
\hline Hepatitis B & 66,232 & 11,269 & 83 \\
\hline Rotavirus (hospitalizations) & 62,500 & 7,500 & 88 \\
\hline Varicella & $4,085,120$ & 449,363 & 89 \\
\hline $\begin{array}{l}\text { Data from table derived from http://www.cdc.gov/vaccines/pubs/pinkbook/downloads/ } \\
\text { appendices/G/impact-of-vaccines.pdf }\end{array}$ & &
\end{tabular}


government-mandated vaccination. In the U.S. and U.K., opponents to vaccination have often been religious. Arguments against variolation, and later vaccination, go back to the eighteenth century, even before Jenner and his discovery of cowpox as protection against smallpox. Preachers pronounced diseases as punishment for sins, and as such should not be treated. A national poll conducted between 2005 and 2010 showed that $60 \%$ of Americans did not want to get flu shots since they worried about side effects and over-vaccination of the population. Recent opposition stems from a report in The Lancet in 1998, linking the measles mumps, and rubella vaccine to the onset of autism. This paper was later withdrawn following the exposure of fabricated data, but the measles vaccine program in the U.K., and to a lesser degree in the U.S., was severely damaged.

A discussion of the history and development of individual vaccines is presented below.

\subsection{Smallpox}

A history of the smallpox vaccine is presented in Chaps. 1 and 9. To summarize: Dr. Edward Jenner (1749-1823), a practicing physician in Berkeley, England (Gloucestershire), had noted, as had others, that milkmaids appeared to be immune to smallpox. Instead, their hands often had blisters picked up from cows who had developed pocks on their teats, later shown to be caused by the cowpox virus (later called "vaccinia"). Jenner, who had a small laboratory in the shadows of Berkeley Castle and its torture chambers in Northern England, inoculated a number of children, including his 11-month-old son first with cowpox, and then reported protection against smallpox. Over 100,000 people had been vaccinated worldwide by the year 1800. Most physicians accepted Jenner's vaccine, although there was some resentment against Jenner by other physicians who did not appreciate that the "cure" for smallpox was developed by a country physician. Others may have resented the loss of revenue from treating smallpox [1]. In 1802, the British Parliament discussed Jenner's vaccine, upheld its usefulness and his claim that he was the inventor of the method. Despite its success, and its use worldwide, there continued to be opposition to the vaccine.

Not with standing this initial success, the production of the smallpox vaccine was plagued with problems. Not least was the method of growing the cowpox virus in amounts large enough to supply the demand. Initially it had to be isolated from pocks on the cow's udder. The virus was unstable over long periods and could not be shipped long distances. It could be kept in dry storage for a few months but could not tolerate heat or exposure to the sun. The supply could not keep up with the demand, since one had to search for cows with cowpox, which was not all that common.

A unique method of transferring the virus was "arm-to-arm"-that is, to transfer the material from one individual after the formation of the scab from the vaccination site to another individual. Although hard to believe, a girl who had 
been recently vaccinated was sent to an orphanage in St. Petersburg, Russia, and served as a source of the smallpox vaccine for all the children more than a week old. The orphanage continued this practice from one child to another for 92 years (1801-93) [2]

Then there was the Balmis Expedition, the goal of which was to bring the vaccine to the New World and the American Indian population. The King of Spain's daughter had been stricken with smallpox in 1798. In 1803, Charles IV ordered his personal physician, de Balmis, to deliver the vaccine to the inhabitants of North and South America. To maintain the vaccine during its long trip across the Atlantic, de Balmis recruited 22 young boys from orphanages in Spain, ages 3-9, who had never had smallpox. During the trip, de Balmis sequentially vaccinated the boys in a living chain and this was continued until the ship reached Venezuela. More than 100,000 people were thus vaccinated in Latin America. The "Royal Smallpox Expedition," as it was called, then recruited 22 more orphans and continued the vaccination program in the Philippines, Macao and Canton [2].

At a medical congress in France in 1864, a better method of growing the virus was reported from Italy and spread worldwide after the presentation. Cowpox could be grown in large quantities by making a series of cuts in the flank of a calf, inoculating the virus into the animals' skin, and harvesting the material from the pocks 5 days later. This was still a crude way of preparing the vaccine, since it was often contaminated with hair, bacteria, and other debris.

Around 1800, a Dr. J. Clinch, a medical missionary in Newfoundland, began using Jenner's vaccine, and by the end of 1801 he had vaccinated approximately 700 people. This was probably the first vaccination of a community in North America. By 1821 compulsory vaccination of infants was in place in Bavaria, Denmark, Norway, Bohemia, Russia and Sweden. The British government passed the vaccination act in 1840, after a smallpox epidemic from 1837 until 1840, made variolation illegal and supplied smallpox vaccine (cowpox) free of charge. In 1853 the Vaccination Act was passed, requiring all children to receive smallpox vaccines by the age of 4 months; later on, the law was changed to allow parents who objected to vaccination to appeal. This was known as the conscientious objection law, hence the term "conscientious objector." In 1905 the U.S. Supreme Court ruled that individual states could impose mandatory vaccination on children.

Despite this, or perhaps because of compulsory vaccination, there were many who continued to oppose vaccination. One of the problems was that Jenner erred when he proclaimed that immunity would last a lifetime. In fact, the immune effect lapsed after 5-10 years and required re-inoculation. Others still objected on religious grounds, saying that it was interference in the "work of the Lord" and there was quite a high level of accidents, in which vaccine was not directly taken from pockmarks of the udder, and was contaminated with other viruses or bacteria. In particular, cases of syphilis were reported both in the "arm-to-arm" method and sometimes from the vaccine itself.

There was quite an active anti-vaccine campaign (see illustrations below of pamphlets and posters from the Library of Medicine Website http://www.nlm.nih. gov/copyright.html) (Fig. 19.1). 


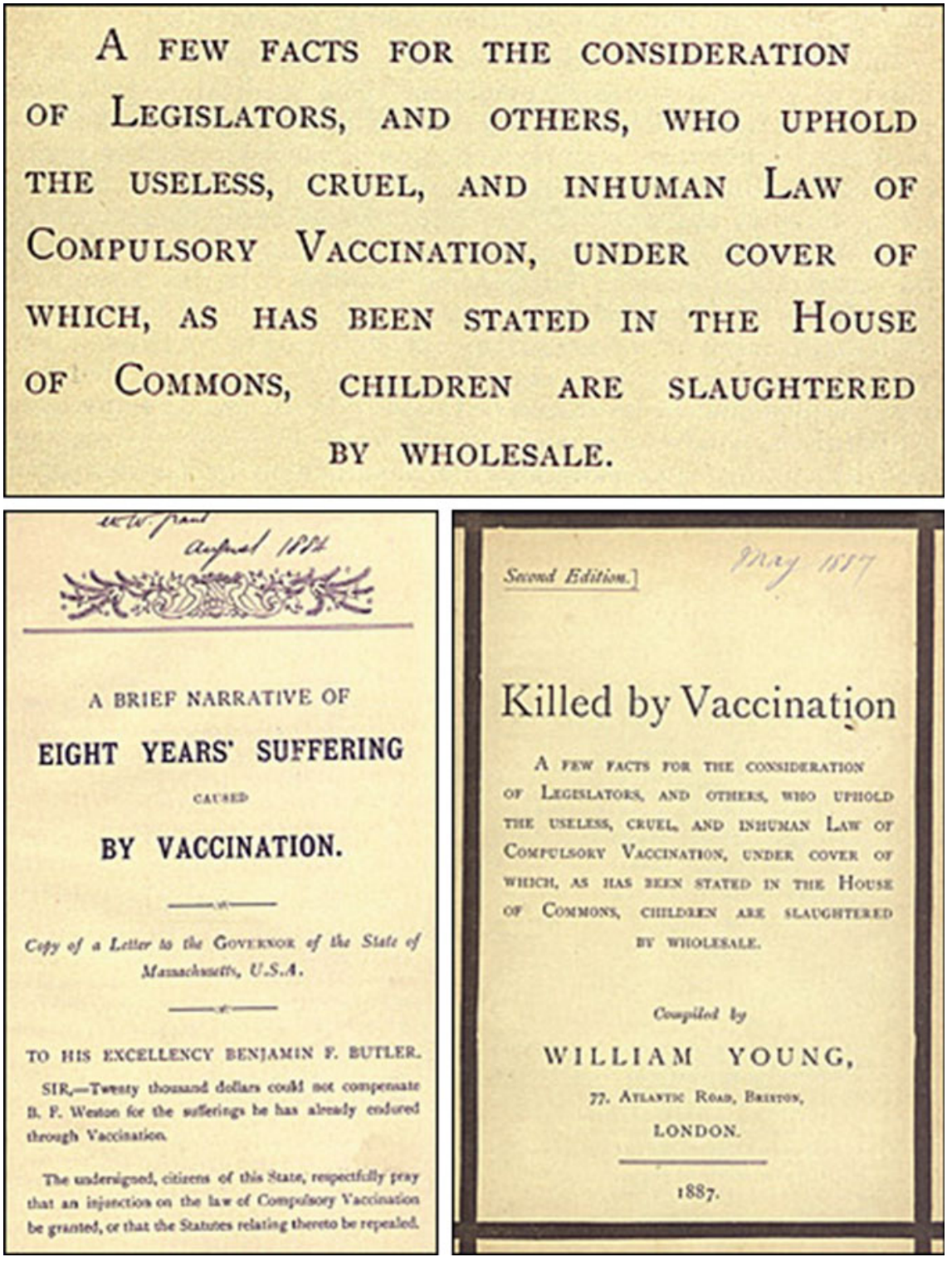

Fig. 19.1 Posters urging the rejection of compulsory vaccination

Smallpox was declared eradicated from the world in 1980, after an intensive struggle to eradicate the virus. In fact, eradication began in 1803 when the Spanish crown attempted to vaccinate the population of the Philippines. In 1813 the U.S. Congress passed the vaccination act to insure safe vaccines for the U.S. public. By 
1832, the U.S. government had set up a program for the vaccination of American Indians. There was also a piecemeal attempt to eradicate the virus in areas of the world, such as India and the East Indies. By 1897 smallpox had been eliminated from the U.S. and by the beginning of the twentieth century from most industrialized countries of Europe. Despite this, each year of the 1950s, two million people died from the disease. In 1959 the United Nations launched a campaign to eradicate smallpox from the world, and although it took longer than expected, the last case of naturally occurring smallpox was in Somalia in 1977.

Smallpox was easier to eradicate than most other viruses for the following reasons:

1. It is an acute infection that is neither chronic nor persistent.

2. There is no non-human reservoir or intermediate vector.

3. Only one species of the virus is very pathogenic.

4. The vaccine is relatively stable and easy to deliver.

As discussed elsewhere, this did not completely eliminate the virus from the world, since stocks were retained for "research" purposes in the U.S. and Russia. Unfortunately the Soviet Union grew the virus in large quantities for biological warfare purposes.

Vaccination was stopped in the U.S. and most of the world in 1972. With the advent of global terrorism and the development of biological weapons, it seemed sensible to reintroduce vaccination against smallpox rather than wait for some tragic event. Although there are reports of adverse effects in some cases, these do not warrant the complete cessation, considering the fact that vaccination was successful for over 100 years.

The smallpox vaccine became the model for the development of other vaccines. Vaccines were based on the similarity of one virus to another, producing crossreacting antibodies. The current vaccine is derived from a clone of the virus originally grown in calves and now produced in cell culture. The virus has changed through many passages, and is no longer "cowpox" but a novel "poxvirus," which for years has been called "vaccinia." The original Jenner "cowpox" has been lost.

\subsection{Rabies}

Rabies is an extremely frightening and dangerous infection, and folklore is rife with stories of rabid dogs attacking humans. Rabies virus triggers foaming at the mouth by stimulating the salivary glands to produce copious amounts of saliva for the efficient transmission of the virus. Pasteur and Roux developed a rabies vaccine in 1885 . The virus was attenuated by passing the most virulent strain isolated from rabid dogs through rabbits' brains, harvested from the nerve tissue, and dried for 5-10 days, resulting in an attenuated virus. The vaccine was delivered to patients in the form of 10-14 intramuscular injections over a period of 2 weeks to anyone suspected of having been in contact with a rabid animal. 
The development of this vaccine is mired in controversy since it has been claimed that it was not adequately tested before being used on a young nine-yearold boy, Joseph Meister. Emil Roux, a young colleague of Louis Pasteur's, was studying for his MD degree and using the development of the rabies vaccine as a research topic. Pasteur was an experimental scientist working on the vaccine, but was not allowed by French law to treat patients. Joseph Meister had been mauled by a rabid dog and was brought to Pasteur for help. Pasteur consulted with two physicians, and since there seemed little hope of a cure since rabies is fatal, asked one of the physicians to administer the untested vaccine. Using it on Meister has come into some criticism and controversy in recent years [3] with the release of Pasteur's notebooks. Questions are being asked whether the vaccine was adequately tested before being used in the Meister case, and doubts have been expressed as to whether the boy had been bitten by a rabid dog. Both Pasteur and Roux worked on the vaccine, but Roux's name is not on the paper reporting the treatment of Meister. Some [3] claim that Pasteur lied in his paper, stating that he had treated 40 dogs with the vaccine, when in fact he had just initiated treatment with 20 dogs, and that development of the vaccine was not far enough along to warrant use in humans; there is also speculation that Roux might have opposed the use of the vaccine.

There is obviously a moral question here: What does one do when there is a possibly fatal case or illness? Wait until experimentation is complete? This is an enigma facing many physicians today when faced with new, but untested treatment for cancer or AIDS. Pasteur's work with the rabies vaccine met with much skepticism in the U.S. Doubts were expressed on the efficacy of the vaccine, and whether the vaccine itself led to the deaths of victims, who might not have been exposed to a rabid dog but bitten by a healthy one.

In 1967 a vaccine was developed from attenuated rabies virus grown in cell culture. This vaccine was extensively tested, and four or five subsequent injections resulted in complete protection. Further improvement to the vaccine was made in 1971 by growing the rabies virus in human embryonic cells. Although Hilary Koprowski's team inoculated themselves with this new vaccine, the medical profession did not like the idea of using a "live" rabies virus. Koprowski also cloned the rabies virus glycoprotein into vaccinia and this vaccine is used to control the disease in wild animals [4]. In 1976 an inactive rabies vaccine, called human diploid cell vaccine (HDCV) was licensed in Europe and in 1980 in the U.S. One of its major advantages was that it was administered in five injections rather than the 14-21 injections of the older vaccine, and this cell culture inactive virus vaccine is now the one of choice.

In the 1950s while tending sheep I found an injured animal. Since I handled it, it was suggested I get rabies shots, in case a rabid jackal had bitten the animal. This was in the days before the modern vaccine, and I was given a series of 12 shots in the abdomen as a precaution (I assume that this must have been the Pasteur vaccine). After the shots the animal tested negative! 
The number of deaths from rabies in the United States had declined from approximately 100 at the turn of the last century (1900) to one or two per year, and those few cases are due to exposure to wildlife (bats). In the rest of the world, the main source of rabies is still the rabid dog. More than 55,000 people die of rabies each year in Asia and Africa; $40 \%$ of those bitten by suspect rabid animals are children less than 15 years old (WHO report).

\subsection{Yellow Fever}

When the Panama Canal opened in 1912, there was an urgent need for a vaccine against yellow fever. Although transmitted by mosquitoes, the agent responsible was still unknown. The Rockefeller Institute in New York sent one of its scientists, Hideyo Noguchi, to Guayaquil, Ecuador, a center for epidemic outbreaks, to investigate the possibilities of producing a vaccine. While in Ecuador, Noguchi claimed to have discovered the agent causing yellow fever, a spirochete bacterium, Leptospira icteroides [5]. He went on to develop a vaccine from this organism and used it extensively in South America and Africa. Noguchi published many papers reporting success with his vaccine, in a total of 7,964 cases. However, his results were not reproducible, filters retained the agent he used, indicating that it was not a viral disease, the statistics were faulty, and eventually the Rockefeller Institute dropped the project. This material is also presented in Chap. 10.

In 1925 the Rockefeller Institute launched another scientific expedition, this time to West Africa to determine whether African yellow fever was identical to South American yellow fever. The aim was to characterize the causative agent, including further search for Leptospira icteroides (the organism studied by Noguchi), and to study its epidemiology. The expedition was led by Major Henry Beeuwkes, a Johns Hopkins-trained bacteriologist retired from the army, and Adrian Stokes, a London-based professor of pathology and expert on leptospirosis; Noguchi and others joined him.

In June 1927, blood from a 28-year-old African yellow fever victim named Asibi, was injected into a rhesus monkey. The monkey became ill, had symptoms of yellow fever and became, thus, the first case of an animal model for yellow fever. A short while later, Stokes himself died of yellow fever. Noguchi pursued his ideas that the disease was caused by Leptospira icteroides and inoculated over one thousand monkeys with blood from yellow fever victims, but could not find any leptospira in them. Noguchi also contracted yellow fever and died in May 1928, as did a third investigator, who performed the autopsy on him [6]. However, now that an animal model had been discovered, the infecting agent could be removed to the laboratory for further study. Soon after, it was shown that serum from immune humans, who had recovered from the infection, protected monkeys against infection, and immune serum from South American patients protected against the African "virus" (thus suggesting that one vaccine would offer protection globally). This strain of yellow fever was called "Asibi." 
A French group in Dakar also collected blood from another patient, and passaged the "virus" in rhesus monkeys. This gave rise to a strain of virus known as the French strain. The virus could be frozen and work now pursued in the laboratory.

Max Theiler, a South African working at the Rockefeller Institute, had been involved in research on Leptospira icteroides, the organism proposed by Noguchi as the causative agent of yellow fever. In 1927 he isolated a virus that appeared to be the causative agent of the disease. Being aware of the previous literature on the rabies virus, and on recent work on growing herpes virus in the brain of mice, Theiler inoculated the yellow fever virus into mouse brains and found that it reproduced. When injected into rhesus monkeys, the passaged virus was less pathogenic systemically, but more neurotropic. This research was extremely dangerous. The Rockefeller Institute announced in 1931 that there had been 32 cases of yellow fever in eight laboratories, with five fatalities. The French strain, passaged a hundred more times in mouse brains, was administered to protect laboratory and field workers in 1931. The virus was combined with immune serum from yellow fever-infected lab workers to prevent encephalitis. This vaccine was successful and was used up until World War II. Meanwhile, the French scientists developed a different vaccine, using the mouse brain passaged virus, coating it with oil or egg yolk, freeze-drying the mixture, suspending it in saline, and applying it with the smallpox vaccine by scarification. By 1945, sixteen million Africans had been vaccinated with this combination and with few side effects.

The method originally developed by Theiler required large amounts of human serum; since there was fear of the neurotropic effects, it was thus of limited use. By the 1930s, cell culture had been introduced, and Theiler passaged the virus in chick embryos lacking nervous tissue more than 100 times. This virus lost its neurotropism in mice, due to random mutations. This strain, called 17D, had no side effects, and became the vaccine of choice. By 1939, 1.3 million people had been vaccinated in South America with the Theiler vaccine, without any side effects. However, in 1941, 119 cases of encephalitis were reported, all of the infected having received the vaccine from a single lot; this virus had apparently mutated during sub-culture. Thus there arose the "seed lot" system, where original cultures of the virus were stored for further use.

World War II saw a huge demand for the vaccine for the troops engaged in North Africa. Between January 1941 and April 1942, 7 million doses were distributed. One batch of vaccine did have a serious side effect-there were 26,772 cases of jaundice that occurred about 60-120 days after the injection. The vaccine contained a small amount of human serum for stabilization, and some batches were contaminated with hepatitis B. It was thus decided to switch to a serum-free vaccine and to give the vaccine only to those posted to a yellow fever area [6]. After further improvements, the 17D strain was adapted as the sole yellow fever vaccine, and it is still used today. 


\subsection{Poliovirus}

Tremendous efforts went into developing a polio vaccine in the 1940s and 1950s (this is discussed in Chaps. 3 and 12). A major advance was the discovery that both poliovirus and mumps virus could grow in mouse lung cells. Three major research groups were involved in the development of a polio vaccine: those of Jonas Salk, Albert Sabin and Hilary Koprowski. Unfortunately, there was bitter competition and rivalry between the three groups. The first vaccine licensed in the U.S. was Salk's inactivated polio vaccine (1955), in which the three strains of poliovirus were inactivated by treatment with formalin. The development of this vaccine was a great achievement, and Jonas Salk became a national hero. A second attenuated vaccine containing all three strains of polio was tested and licensed in 1962. Two other groups had independently produced an attenuated vaccine-one headed by Albert Sabin, the other by Hilary Koprowski. A committee of the National Institutes of Health decided on the Sabin vaccine, which consisted of the three mutated strains of polio, extensively passaged in cell culture and mice. Hilary Koprowski had developed the first attenuated poliovirus in 1950 and tested it on himself and on a group of 20 children in New York, with no side effects. Mass vaccination trials of the Koprowski oral polio vaccine took place in the Belgian Congo, Poland, Croatia, and Switzerland. By 1960, approximately 13 million individuals had been vaccinated with the Koprowski polio vaccine and over 11 million with the Sabin vaccine [7].

The Salk vaccine is based on three wild, virulent reference strains, Mahoney (type 1 poliovirus), MEF-1 (type 2 poliovirus), and Saukett (type 3 poliovirus), grown in monkey kidney cell culture (Vero cell line), and the virus inactivated with formalin. Initially, the Salk vaccine was the vaccine of choice in the U.S. In 1955 , in the largest trial ever held, more than 400,000 children were vaccinated with the Salk vaccine, which was $90 \%$ effective against type II and type III polio, and 60-70\% effective against type I. Large industrial facilities were built for the production of the vaccine, which was exported to many countries. In 1955, in an event known as the "Cutter" (Cutter was the name of one of the pharmaceutical companies that produced the polio vaccine), some 120,000 doses of the Salk vaccine were created, containing a live poliovirus instead of an inactive one. The administration of this vaccine caused 40,000 cases of polio, with 53 cases of paralysis and 5 deaths. The disease spread, creating a polio epidemic that lead to a further 113 cases of paralytic polio and another 5 deaths. It has been called "one of the worst pharmaceutical disasters in U.S. history;" [8] it of course affected the public's attitude towards the vaccine. In order for a vaccine to be successful, the public has to have confidence in it. In fact, the "Cutter Incident" led to the use of an alternative vaccine (Sabin instead of Salk) for some time.

Many health advocates believed that the Sabin vaccine was a better vaccine, since as a "live" vaccine, it provides "herd immunity" - that is, virus is shed by those being vaccinated-and it can spread throughout the family and provide protection to the surrounding population. It was also assumed that the immunity from the inactivated vaccine would not be long lasting, whereas the Sabin vaccine 


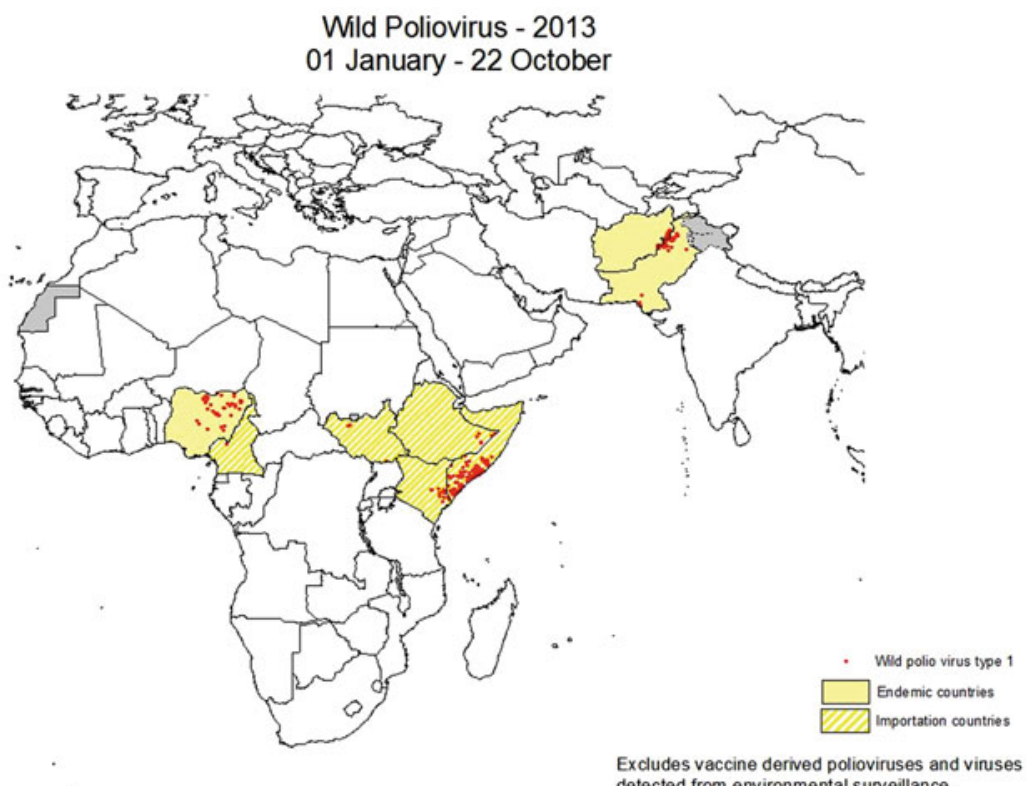

Data in HQ as of 22 October 2013 detected from environmental surveillance.

Fig. 19.2 Map of polio endemic areas as of 2013

virus multiplied in the gut, and would confer a stronger immune response. By 1968 the Sabin vaccine replaced the Salk vaccine. Since it was given orally rather than by injection, it was easier for children to take and for parents to administer. However there was a low, but steady number of individuals receiving the vaccine who developed paralytic polio, indicating that the attenuated virus had undergone mutation, or reverted to wild-type. By 2000 the US CDC recommended the Salk, inactivated vaccine. In the WHO campaign to eradicate polio, the oral vaccine is preferred, because of herd immunity. A map of the areas of the globe with endemic polio is shown in Fig. 19.2 (a newer map would include Syria).

\subsection{Measles}

In the 1960s, vaccines were developed for mumps, rubella (German measles) and measles, and in 1971 the combination of all three viruses (MMR vaccine) was approved for use in the U.S. All three viruses are derived from attenuated strains by passage through chicken eggs or cell culture, and were developed by Maurice Hilleman of Merck Pharmaceuticals; in fact, Hilleman was responsible for the development of 36 vaccines. Of the 14 vaccines routinely recommended in current vaccine schedules, he developed eight: for measles, mumps, hepatitis $\mathrm{A}$, hepatitis $\mathrm{B}$, chickenpox, meningitis, pneumonia and Haemophilus influenzae bacteria (Wikipedia). 


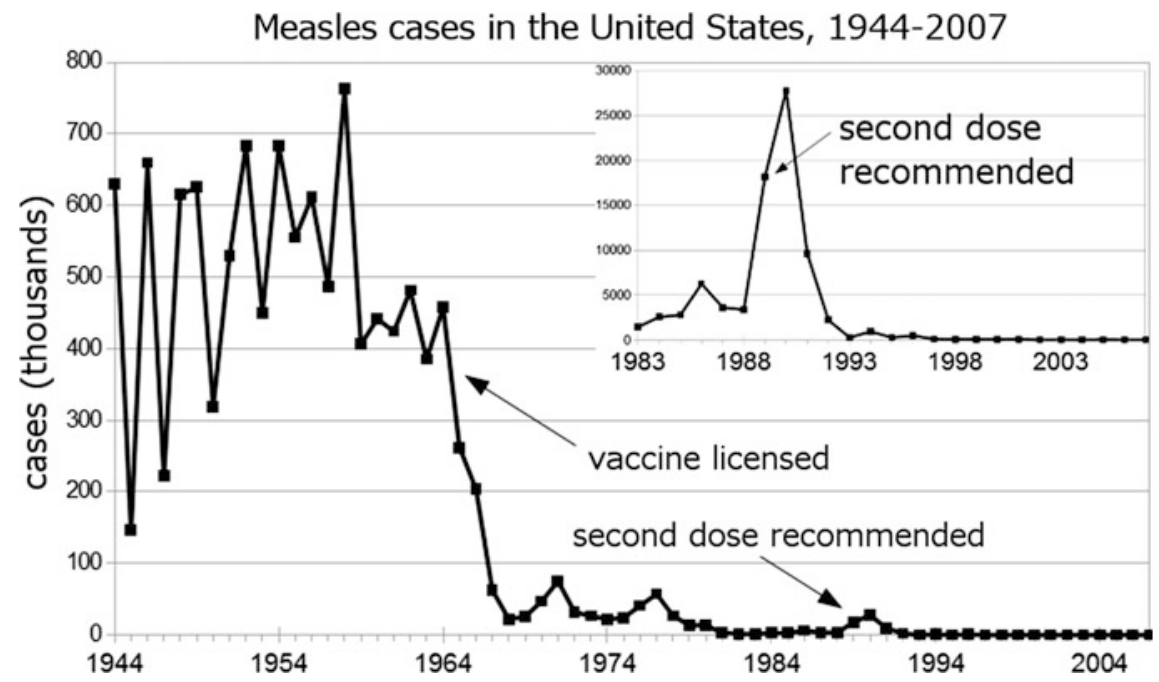

Fig. 19.3 Number of cases of measles in the USA, and decline after introduction of the vaccine (from Wikipedia and CDC)

Measles is a very dangerous childhood disease, leading in some cases to death, blindness, or hearing difficulties. Since the introduction of the vaccine, the number of cases in the U.S. has fallen drastically (Fig. 19.3).

\subsubsection{Measles Vaccine and Autism}

In 1998 [9] a paper appeared in The Lancet, the influential British medical journal claiming that the increase in cases of autism in children was linked directly to the MMR vaccine. This was based on a study headed by Dr. Andrew Wakefield, a British surgeon and specialist in diseases of the gastric tract. In particular, he claimed to have found a correlation between irritable bowel syndrome, autism and the vaccine. His conclusions were based on a study of 12 children. Most of the data presented in the paper was anecdotal, on information from the parents as to when the autistic symptoms first appeared. In most cases this was said to have been within a few weeks of the MMR inoculation. Dr. Wakefield published a follow-up series of papers [10-12] claiming a direct relationship between the vaccine and autism (and irritable bowel syndrome or Crohn's disease). The papers were peerreviewed, many appearing in The Lancet or other influential peer-reviewed journals. The major argument presented was that (1) the vaccine overloaded the immune system with viruses (three types), leading to an abnormal immune response; (2) the injection of measles virus at such a young age altered the normal immune response, resulting in aberrations of the immune system; and (3) that lack of natural exposure to these viruses could lead to irritable bowel syndrome and 
Crohn's disease, both autoimmune diseases (although also known to be inherited). These reports caused an uproar in the U.K., resulting in many parents refusing to vaccinate their children; the effects were such that the level of MMR vaccination dropped from 93 to $73 \%$ in the U.K., and to $50 \%$ in London.

Within a few years, large studies were performed to confirm or refute Wakefield's data. One of the largest was a Danish study with 537,303 children in the cohort-children who had received MMR and children who had not received it [13]. No correlation between the MMR vaccine and autism was detected. Other studies quickly followed, showing similar results, although the Wakefield group continued publishing the opposite conclusions. It was not until 2010 that 10 of 12 authors in the first paper published in The Lancet [14] retracted their authorship, claiming that they did not agree with the conclusions of the paper. Similar retractions were made in other journals, but by then a great deal of damage had been done. During this period, Wakefield stood by his results and claimed that there was a conspiracy against him. What is astounding is that none of the coauthors on the original paper realized that the data was wrong (or not statistically correct) and that the retraction took so long. An investigation by the General Medical Council of Great Britain found that many of the co-authors could not identify which child was being discussed in the paper. Their names, with their agreement, had been added to the authorship of the papers for the flimsiest of reasons; unfortunately, this is a common occurrence in science today.

The Wakefield case came to prominence due to the investigative reporting of Brian Deer of the Times of London. Deer published his first investigation into Wakefield's papers in 2004. He uncovered the possibility of research fraud, unethical treatment of children, and Wakefield's conflict of interest through his involvement in a lawsuit against manufacturers of the MMR vaccine. Deer published a summary of his work in the British Medical Journal in 2011 [15, 16]. He interviewed each of the parents of the 12 (probably 13) children described in the Wakefield paper, and found that the time of appearance of autism did not match that reported in the 1998 paper, nor were the medical records reported correctly. This is shown in Table 19.4.

The summary of the BMJ paper [9] is presented below:

"The Lancet paper was a case series of 12 child patients; it reported a proposed 'new syndrome' of enterocolitis and regressive autism and associated this with MMR as an "apparent precipitating event." But in fact:"

"Three of nine children reported with regressive autism did not have autism diagnosed at all. Only one child clearly had regressive autism."

"Despite the paper claiming that all 12 children were "previously normal," five had documented pre-existing developmental concerns."

"Some children were reported to have experienced first behavioral symptoms within days of MMR, but the records documented these as starting some months after vaccination."

"In nine cases, unremarkable colonic histopathology results-noting no or minimal fluctuations in inflammatory cell populations-were changed after a medical school 'research review' to 'non-specific colitis'." 
Table 19.4 Comparison of three features of the 12 children in the Lancet paper with features apparent in the NHS records, including those from the Royal Free Hospital

\begin{tabular}{|c|c|c|c|c|c|c|c|c|}
\hline \multirow[t]{2}{*}{ Child } & \multicolumn{2}{|c|}{$\begin{array}{l}\text { Regressive } \\
\text { autism }\end{array}$} & \multicolumn{2}{|c|}{$\begin{array}{l}\text { Non-specific } \\
\text { colitis }\end{array}$} & \multicolumn{2}{|c|}{$\begin{array}{l}\text { First symptoms days after } \\
\text { MMR }\end{array}$} & \multicolumn{2}{|c|}{ All three features } \\
\hline & Lancet & Records & Lancet & Records $\dagger$ & Lancet & Records $\ddagger$ & Lancet & Records \\
\hline 1 & Yes & $?$ & Yes & Yes & Yes & No & Yes & No \\
\hline 2 & Yes & Yes & Yes & Yes & Yes & No & Yes & No \\
\hline 3 & Yes & $?$ & Yes & No & Yes & $?$ & Yes & No \\
\hline 4 & Yes & $?$ & Yes & No & Yes & No & Yes & No \\
\hline 5 & Yes & $?$ & Yes & No & No & No & No & No \\
\hline 6 & Yes & No & Yes & Yes & Yes & $?$ & Yes & No \\
\hline 7 & Yes & No & No & No & Yes & No & No & No \\
\hline 8 & No & No & Yes & No & Yes & No & No & No \\
\hline 9 & No & No & Yes & No & No & No & No & No \\
\hline 10 & No & No & Yes & No & No & No & No & No \\
\hline 11 & Yes & $?$ & Yes & No & Yes & No & Yes & No \\
\hline 12 & Yes & No & Yes & No & No & No & No & No \\
\hline Total & $9 / 12$ & $? 6 / 12$ & $11 / 12$ & $3 / 12$ & $8 / 12$ & $? 2 / 12$ & $6 / 12$ & $0 / 12$ \\
\hline
\end{tabular}

"The parents of eight children were reported as blaming MMR, but 11 families made this allegation at the hospital. The exclusion of three allegations-all giving times to the onset of problems in months-helped to create the appearance of a 14 day temporal link.

"Patients were recruited through anti-MMR campaigners, and the study was commissioned and funded for planned litigation."

As a scientist, it is difficult to discern a motive for this falsification of data. Was it done out of greed? This does seem to be the case. All the shenanigans-creating companies to show a linkage between MMR and autism and Crohn's disease even before the children described in the Lancet paper were hospitalized-are presented in http://briandeer.com/mmr/lancet-summary.htm. Companies were created in England, Ireland and in the U.S., patents were applied for, and money accepted from charitable and government agencies on the basis of false data. The hospital and institutions employing Wakefield were only too pleased to take their cuts.

"Moreover," Deer reported, "a lawyer planning to sue vaccine manufacturers on behalf of parents who thought MMR caused their children's problems retained Wakefield as an expert witness 2 years earlier. The parents cited in the Lancet article came to Wakefield's clinic in response to an advertising campaign led by the lawyer's group, called Jabs, and not for routine screening." From the London Times: "ANDREW WAKEFIELD, the former surgeon whose campaign linking the MMR vaccine with autism, caused a collapse in immunization rates, was paid more than $£ 400,000$ by lawyers trying to prove that the vaccine was unsafe. 
The payments, unearthed by The Sunday Times, were part of $£ 3.4 \mathrm{~m}$ distributed from the legal aid fund to doctors and scientists who had been recruited to support a now-failed lawsuit against vaccine manufacturers.

"Critics this weekend voiced amazement at the sums, which they said created a clear conflict of interest and were the 'financial engine' behind a worldwide alarm over the triple measles, mumps and rubella shot.

"According to the figure, released under the Freedom of Information Act, Wakefield was paid $£ 435,643$ in fees, plus $£ 3,910$ in expenses. Wakefield's work for the lawyers began 2 years before he published his now notorious report in The Lancet medical journal in February 1998, proposing a link between the vaccine and autism."

It is interesting that the Wakefield 1998 paper has been cited more than any other retracted paper, over 700 times [10]. The vaccination rate in the U.K. has not completely recovered".

\subsection{Influenza}

In the U,S, the annual morbidity from influenza is estimated at between 25-50 million cases with 225,000 hospitalizations. The WHO, extrapolating from these numbers, estimates that there are 1 billion cases of influenza annually, with 3-5 million severe cases and 300,000-500,000 deaths. Most of the deaths in the U.S. are in the over-65 age group [11]. Chapter 11 presents the biological aspects of the influenza virus. The major antigenic components of the virus are the hemagglutinin protein and the neuraminidase protein, the major surface proteins of the virus. As discussed in Chap. 11, the virus undergoes random mutation at a high rate, resulting in antigenic drift. Reassortment and even mixing in the case of two viruses of different origins results in antigenic shift, making it difficult to predict the makeup of the virus causing the seasonal outbreak of the flu. The result of the antigenic changes may mean that a population has no immunity to the virus, and infection can result in a pandemic, as happened in 1918. The vaccine has to be "predictive" from year to year.

There are three types of influenza vaccine currently in circulation. One, containing inactivated subunits of the virus, is given intramuscularly or intradermally; the second is a live vaccine (LIAV live attenuated influenza vaccine) and is given intranasally. Both vaccines are trivalent-that is, have three species of influenza virus in the vaccine. A live attenuated cold adapted influenza virus can be administered as a nasal vaccine. FluMist contains three cold-adapted H1N1, $\mathrm{H} 3 \mathrm{~N} 2$, and B influenza. These are recombinant viruses containing a backbone of a virus grown in the cold, with the incorporation of $\mathrm{H}$ and $\mathrm{N}$ genes from different sources, and also influenza B. Mean shedding of the virus is for 7-8 days and longer in children, thus having a herd effect. There have been no cases of illness from this vaccine in the USA. 
Fig. 19.4 Various methods of producing influenza vaccines

\section{Influenza Vaccine Production}

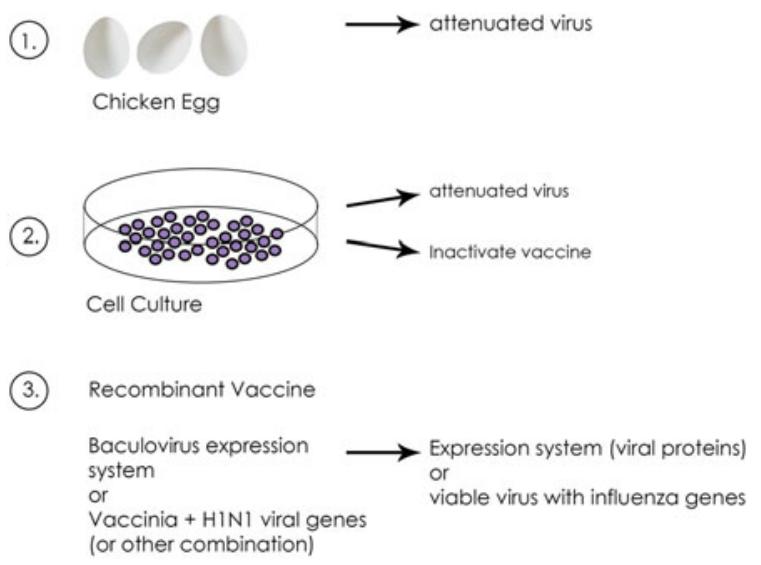

The CDC introduced a new vaccine this year. The quadrivalent flu vaccine protects against two influenza A viruses and two influenza B viruses. A standard dose of quadrivalent flu vaccine, given as a nasal spray, is approved for healthy people aged 2-49; each year the vaccine changes according to predictions of the type of influenza likely to be prevalent in a particular year. For 2013, the FDA chose A/California/7/2009 (H1N1): A/Victoria/361/2011(H3N2) and B/Wisconsin/1/2010 - two strains of influenza A and one strain of influenza B. People over 65 should get a new high dose inactivated virus vaccine annually. The strains for the next year's vaccine are chosen in February for use in the following season, and vaccine production begins with strains carrying the "drifted" HA and NA genes of the last season combined with reference strains that grow well in chick eggs. New methods of producing vaccines, in which reverse genetics is used to copy genes, which are inserted into plasmids, and then cloned back into a reference strains of influenza have been developed. New technologies are required to produce sufficient influenza vaccines, and some are already being tried in various companies. These include cell-based rather than egg-based live attenuated and inactive viral vaccines as well as recombinant protein vaccines, where the genes for HA and NA are cloned into baculovirus vectors and administered as purified proteins. Influenza virus gene can also be cloned into other viral vectors such as vaccinia virus or adenovirus and administered as either a replication-competent virus or defective virus (Fig. 19.4). However, this creates problems discussed in the chapter on gene therapy, where antibodies may inactivate such a virus. The development of an influenza vaccine is to some extent a "guessing game," since one cannot predict the appearance of a novel strain of virus. 


\subsection{Rational Approach to Designing Vaccines}

Vaccines fall into many categories. The majority of those discussed above are live virus vaccines in which the virus has been attenuated either by multiple passages through other animals or through multiple passages through cells in culture. During passage, the virus undergoes mutation (particularly if it is an RNA virus) at a very high rate, and the virus emerging is often attenuated. It should be possible to rationally design mutations by in vitro mutagenesis. Influenza vaccines are made by adapting the virus to grow at lower temperatures and could be made by performing re-assortment in the laboratory to make attenuated strains (although recombination in the laboratory might also produce viruses that are more pathogenic). Another approach is to make recombinant vaccines using viral genes produced in bacteria, yeast or baculovirus systems.

The vaccine for hepatitis $\mathrm{B}$ is a recombinant vaccine produced in yeast. In Europe a second vaccine is produced in Chinese hamster ovary cells. These vaccines are very highly immunogenic and have few side effects. Large-scale studies have been performed in at-risk patients, and antibody titers have been high. The WHO_with the goal of eradicating HBV - has recommended a universal vaccination program. In Taiwan and Italy, mass vaccination of infants has not only decreased the incidence of HBV infection and the prevalence of chronic carriers, but also the incidence of hepatocellular carcinoma.

Yeast and an insect virus, baculovirus, have also been used to produce the human papilloma virus vaccine. Two vaccines have been developed; both are highly immunogenic. Gardasil (Merck and Co.) is a quadrivalent vaccine against HPV type 6, 12, 16 and 18, while Cervarix (Glaxo Smith Kline Biologicals) is against HPV types 16 and 18. Both vaccines give excellent protection. Gardasil also demonstrated strong protection against genital warts and anal cancers [12].

There has been some controversy surrounding the recommendations for papilloma vaccination. The vaccines are recommended for girls and women aged 9-46 who have not been exposed to HPV. The vaccine has also been approved for men and boys, with the CDC recommending it for boys as young as 9. There has been fear expressed in the public and newspapers that giving the vaccine to teenagers will encourage promiscuity.

Other alternatives proposed for the development of vaccines, include the use of purified proteins, viral proteins expressed by prokaryotes, the use of synthetic peptides and even DNA. Proteins from a variety of viruses have been cloned and expressed in prokaryotes and cells in culture. Most have proven effective in mice but have not been approved by the appropriate regulatory bodies. DNA vaccines, coding for antigens from cancer or specific bacterium such as anthrax are delivered as plasmids are delivered as plasmids or in harmless strains of E. coli. The major problem with DNA vaccines has been a weak antigen response. The main method of delivery is intramuscular injection or application to the skin with a gene gun [13]. However, a large number of clinical trials with DNA vaccines are under way. 


\subsection{Vaccines from Plants}

One of these days, it may be possible to eat lettuce and be vaccinated at the same time, or receive antibodies against a bacterial or virus infection. It sounds like science fiction, yet experimental trials of producing viral antigens are under way, both in the research laboratory and in biotech companies, by introducing animal viral genes into the plant genome, and into chloroplasts. Chloroplasts are small organelles of prokaryotic origin that are responsible for photosynthesis in green plants, analogous to mitochondria in higher organisms. Plant-derived vaccines (or other biopharmaceuticals) are cheap to produce (compared to cell culture) and to store, easy to scale up for mass production, and safer than those produced from other sources, since there is less likelihood of contamination by bacteria or even other viruses. Plant systems are much more economical than other industrial systems for producing vaccines and would be ideal for Third World countries. For example, it is estimated that to produce 100 million doses of influenza vaccine by a conventional pharmaceutical company, such as Sanofi in Pennsylvania, would cost $\$ 150$ million per year. If Novartis were to produce 300 million doses, they would charge $\$ 100$ billion. Using tobacco plants, the cost would be $\$ 15$ million per year to produce one billion doses [14]. The technology is already available for the purification, if necessary, of the products, although the ultimate aim might be to digest the vaccine (oral vaccine), despite the fact that precautions need to be taken that the vaccine is not itself digested by stomach enzymes (this obviously does not apply to tobacco plants). To date, the yield of products in experimental systems such as tobacco or lettuce or grains has not been as great as expected; however, the yield can be greatly enhanced by cloning the desired viral genes into chloroplasts, which multiply in large numbers in the plant cell, thus enriching the product. An HSV-2 vaccine has been produced in soybeans using a cauliflower mosaic virus promoter [15]. This antibody was effective in preventing HSV-2 infection in a mouse model and was indistinguishable from a monoclonal antibody produced in cell culture. A whole series of monoclonal antibodies have been produced in a variety of plants using plant virus vectors [16]. The hepatitis B envelope protein has been produced in potatoes, lettuce, and lupines, and was immunogenic when digested orally. The Norwalk virus capsid protein was also produced in potatoes and tobacco plants and was immunogenic. The protein produced resembled empty viral capsids (Table 19.5).

So far, the amount of foreign or viral proteins produced in the plants has not been sufficient for mass vaccination. This has led to further experimentation to increase the yield by using various promoter sequences, and adding polyadenylation sites (as in mammalian tissue) to increase the yield. It is estimated that the yield should be around $1 \%$ of the total weight to make it of practical use. The yield can be increased by using chloroplasts. There can be upto 10,000 copies of chloroplasts per cell and result in the accumulation of $47 \%$ of the total protein being the recombinant protein. The desired genes are incorporated into the chloroplast by recombination. Thus the cloned gene is surrounded on both sides by 
Table 19.5 Shows those experimental results

\begin{tabular}{|c|c|c|c|}
\hline Source of the protein & $\begin{array}{l}\text { Protein or peptide } \\
\text { expressed }\end{array}$ & $\begin{array}{l}\text { Plant expression } \\
\text { system }\end{array}$ & Immunogenicity \\
\hline Hepatitis B virus & $\begin{array}{l}\text { Envelope surface } \\
\text { protein }\end{array}$ & Tobacco & $\begin{array}{l}\text { Virus-like particles, } \\
\text { immunogenic on injection }\end{array}$ \\
\hline Hepatitis B Virus & $\begin{array}{l}\text { Envelope surface } \\
\text { protein }\end{array}$ & Potato & $\begin{array}{l}\text { Immunogenic when } \\
\text { administered orally }\end{array}$ \\
\hline Hepatitis B virus & $\begin{array}{l}\text { Envelope surface } \\
\text { protein }\end{array}$ & Lupine & $\begin{array}{l}\text { Immunogenic when } \\
\text { administered orally }\end{array}$ \\
\hline Hepatitis B virus & $\begin{array}{l}\text { Envelope surface } \\
\text { protein }\end{array}$ & Lettuce & $\begin{array}{l}\text { Immunogenic when } \\
\text { administered orally }\end{array}$ \\
\hline Norwalk virus & Capsid proteins & Tobacco & $\begin{array}{l}\text { Intact virus and immunogenic. } \\
\text { Oral vaccine }\end{array}$ \\
\hline Norwalk virus & Capsid proteins & Potato & $\begin{array}{l}\text { Virus like particles, } \\
\text { immunogenic, oral }\end{array}$ \\
\hline Rabies virus & Glycoprotein & Tomato & Intact high yield protein \\
\hline $\begin{array}{l}\text { Human } \\
\text { Cytomegalovirus }\end{array}$ & Glycoprotein B & Tobacco & Immunologically related protein \\
\hline $\begin{array}{l}\text { Rabbit hemorrhagic } \\
\text { disease virus }\end{array}$ & VP60 & Potato & Immunogenic \\
\hline $\begin{array}{l}\text { Foot and mouth } \\
\text { disease virus }\end{array}$ & VP1 & Aridopsis & $\begin{array}{l}\text { Immunogenic when } \\
\text { administered by injection }\end{array}$ \\
\hline $\begin{array}{l}\text { Foot and mouth } \\
\text { disease virus }\end{array}$ & VP1 & Alfalfa & Immunogenic when given orally \\
\hline Coronavirus (pigs) & Glycoprotein S & Aridopsis & Immunogenic when injected \\
\hline Coronavirus (pigs) & Glycoprotein S & Tobacco & $\begin{array}{l}\text { Immunogenic when } \\
\text { administered by injection }\end{array}$ \\
\hline Coronavirus (pigs) & Glycoproteins S & Maize & $\begin{array}{l}\text { Protective when administered } \\
\text { orally }\end{array}$ \\
\hline
\end{tabular}

Table 19.4. Adapted from [16]

chloroplast sequences. The method of transformation is quite different from that of animal cells. Four- to six-week-old leaves are selected for transformation; DNA is coated on the surface of microparticles of gold or tungsten and then shot onto the leaf surface with great force, using a helium-driven particle delivery device (gene gun).

Regeneration. Leaves are then cut into small leaf discs after $48 \mathrm{~h}$ of incubation in the dark and put on selection media. Primary shoots generally arise within 4-6 weeks. Initially, a few copies of plastid genome are transformed and leaf cells that are called heteroplastomic. Homoplastomy, a state where all copies of chloroplast genome are transformed, is achieved by performing a few rounds of regeneration under selection. The putative transgenic shoots are then further characterized for transgene integration and protein expression [17]. 
HIV gag protein and dengue virus proteins have been produced in chloroplasts. However, the product has not yet reached human clinical trials, although there has been a large investment by U.S. government agencies. It may take a few more years until we see clinical trials as production techniques are patented. However, this may be the way of the future, producing cheap vaccines for most infectious diseases. This method is now known in the "trade" as "molecular farming" and it may be the answer to vaccine shortage; a number of biotech companies are now pursuing this course. To quote from an announcement by Fraunhofer center for molecular biotechnology (http://www.fraunhofer.de/en/press/research-news/2013/ june/automated-plant-factory-for-the-prodution-of-vaccines.htm) regarding one such plant, "The plants grow in trays with hydroponic cultures of mineral wool as opposed to soil, in specially designed growth modules. Light, water, and nutrients are precisely dosed and distributed. Specially developed robots bring the plants from station to station to carry out the various steps-from inserting the tiny seeds and vacuum infiltration, to harvesting and extraction.

"The plants grow for four weeks before the vector is introduced by means of vacuum infiltration." The process goes as follows: "A robot picks up a tray with plants, turns it upside down, and submerges the tobacco plants headfirst into water." This water holds the vector (biological carrier) containing the genetic information that tells the plants which protein they should produce. Then a vacuum is applied by drawing the air from the water and the plants. As soon as we switch off the vacuum, the plants suck in the water together with the vector. This takes just a few seconds, and then the plants are put back in the growth module to grow further. In about a week they have produced the proteins. Once harvested, the leaves are cut into small pieces and homogenized in fully automated processes. This produces a liquid from which the proteins are extracted. The end product is a clear liquid.

"The pilot facility is capable of producing up to $300 \mathrm{~kg}$ of biomass a month, which roughly corresponds to 2.5 million units of vaccine."

Is this the future of vaccine production?

\section{References}

1. Kotar, S. L., \& Gesser, J. E. (2013). Smallpox: a History. Jefferosn, North Carolina: McFarland and Company.

2. Tucker, J. B. (2001). Scourge. New York: Atlantic Monthly Press.

3. Geison, G. L. (1990). Pasteur, roux, and rabies: scientific versus clinical mentalities. Journal of the History of Medicine and Allied Sciences, 45(3), 341-365.

4. Plotkin, S. A. (2013). In memoriam: Hilary Koprowski, 1916-2013. Journal of Virology, 87(15), 8270-8271.

5. Noguchi, H. (1920). Leptospira Icteroides and yellow fever. Proceedings of the National Academy of Sciences of the United States of America, 6(3), 110-111.

6. Frierson, J. G. (2010). The yellow fever vaccine: a history. Yale J Biol Med, 83(2), 77-85.

7. Koprowski, H. (2006). First decade (1950-1960) of studies and trials with the polio vaccine. Biologicals: Journal of the International Association of Biological Standardization, 34(2), 81-86. 
8. Offit, P. A. (2005). The Cutter incident, 50 years later. New England Journal of Medicine, $352(14), 1411-1412$.

9. Deer, B. (2011). How the case against the MMR vaccine was fixed. $B M J j, 342$, c5347.

10. Fang, F. C., Steen, R. G., \& Casadevall, A. (2012). Misconduct accounts for the majority of retracted scientific publications. Proceedings of the National Academy of Sciences of the United States of America, 109(42), 17028-17033.

11. Lambert, L. C., \& Fauci, A. S. (2010). Influenza vaccines for the future. New England Journal of Medicine, 363(21), 2036-2044.

12. Schiller, J. T., Castellsague, X., \& Garland, S. M. (2012). A review of clinical trials of human papillomavirus prophylactic vaccines. Vaccine, 30(Suppl 5), F123-F138.

13. Smahel, M., Polakova, I., Pokorna, D., Ludvikova, V., Duskova, M., \& Vlasak, J. (2008). Enhancement of $\mathrm{T}$ cell-mediated and humoral immunity of beta-glucuronidase-based DNA vaccines against HPV16 E7 oncoprotein. International Journal of Oncology, 33(1), 93-101.

14. Penney, C. A., Thomas, D. R., Deen, S. S., \& Walmsley, A. M. (2011). Plant-made vaccines in support of the millennium development goals. Plant Cell Reports, 30(5), 789-798.

15. Zeitlin, L., Olmsted, S. S., Moench, T. R., Co, M. S., Martinell, B. J., Paradkar, V. M., et al. (1998). A humanized monoclonal antibody produced in transgenic plants for immuno protection of the vagina against genital herpes. Nature Biotechnology, 16(13), 1361-1364.

16. Daniell, H., Streatfield, S. J., \& Wycoff, K. (2001). Medical molecular farming: production of antibodies, biopharmaceuticals and edible vaccines in plants. Trends in Plant Science, 6(5), 219-226.

17. ZM, Ahmad N. (2013). Green factories: plastids for the production of foreign proteins at high levels. Gene Therapy and Molecular Biology, 15, 14-29. 